\title{
Potentiodynamic Polarization Behavior and Microscopic Examination of Tungsten Carbide Hard Metal Materials in Supported Ammoniacal Medium
}

\author{
Navneet Singh Randhawa ${ }^{a, *}$ and Prvan Kumar Katiyar ${ }^{b, c}$ \\ ${ }^{a}$ Metal Extraction and Recycling Division, CSIR-National Metallurgical Laboratory, \\ Jamshedpur-831007 (India) \\ ${ }^{b}$ Department of Metallurgical and Materials Engineering, Indian Institute of Technology, \\ Varanasi-221005 (India) \\ ${ }^{c}$ Department of Materials and Metallurgical Engineering, Indian Institute of Technology, \\ Kanpur-208016 (India)
}

Received February 26, 2018; accepted February 23, 2019

\begin{abstract}
Electrochemical methods for the recycling of tungsten carbide (WC-10Co) resources suffer from passivation in the acidic medium caused by $\mathrm{WO}_{3}$ and also in $\mathrm{NaOH}$ electrolytes, due to hydroxide formation. We found that an ammoniacal solution is a promising electrolyte for sustainable electrochemical dissolution of both tungsten (W) and cobalt $(\mathrm{Co})$. The ammoniacal medium performs greatly when supported with $\mathrm{Cl}^{-}$, $\mathrm{SO}_{4}{ }^{2-}$ and $\mathrm{CO}_{3}{ }^{2-}$ ions. Poor dissolution/corrosion tendency of WC-10Co in a diluted $\mathrm{NH}_{4} \mathrm{OH}$ solution enhanced many folds in the presence of $\mathrm{Cl}^{-}, \mathrm{SO}_{4}{ }^{2-}$ and $\mathrm{CO}_{3}{ }^{2-}$ ions. Among these supporting ions, $\mathrm{Cl}^{-}$emerged as the most suitable for the electrochemical leaching of $\mathrm{W}$ and Co from the WC-10Co, accompanying the least noble behavior of WC-10Co. An electrolyte composed of $150 \mathrm{~g} / \mathrm{L}$ of ammonia and 5\% (w/v) of $\mathrm{NH}_{4} \mathrm{Cl}$ yielded the maximum anodic current density. Microscopic examination of the electrochemically treated samples shows scattered active sites responsible for the oxidative dissolution of WC-10Co. The usefulness of $\mathrm{W}$ and Co dissolution in ammonia-additive salt followed the order $\mathrm{NH}_{4} \mathrm{OH}-\mathrm{NH}_{4} \mathrm{Cl}>\mathrm{NH}_{4} \mathrm{OH}-$ $\left(\mathrm{NH}_{4}\right)_{2} \mathrm{SO}_{4}>\mathrm{NH}_{4} \mathrm{OH}-\left(\mathrm{NH}_{4}\right)_{2} \mathrm{CO}_{3}$.
\end{abstract}

Keywords: ammoniacal electrolyte, electroleaching, electrodissolution, potentiodynamic, tungsten carbide.

\section{Introduction}

Cemented tungsten carbide (WC) possesses a wonderful combination of very high hardness and good fracture toughness, hence, it is the material of choice for mining and tunneling equipments. However, during the period of use, it also

\footnotetext{
*Corresponding author. E-mail address: nsrandhawa@gmail.com
} 
undergoes wear and corrosion, leading to failure [1-2]. The end-of-life or rejected tungsten carbide hard metal components offers an excellent resource of tungsten and cobalt. Statistics show that the recovered WC comprises about 20 to $30 \%$ of the total supply, lowering the raw material cost by about 15 to $50 \%$ [3]. One of the most used and significant recycling processes is based on the hightemperature treatment of $\mathrm{WC}$ in the molten zinc ( $\mathrm{Zn})$ [4]. In this process, the WC scrap is converted into the WC powder by the selective dissolution of Co binder in a molten $\mathrm{Zn}$ bath. However, it consumes considerably high energy during cobalt dissolution and subsequent evaporation of the molten zinc to recover cobalt.

Table 1. Electrochemical processing for the recycling of WC scrap.

\begin{tabular}{|c|c|c|c|c|}
\hline $\begin{array}{l}\text { Sl. } \\
\text { No. }\end{array}$ & Types of scrap & Electrolyte/additive & Recovery/product & References \\
\hline 1 & Secondary hard & $\mathrm{HNO}_{3}$ & $\mathrm{WO}_{3}$ & {$[11]$} \\
\hline 2 & $\begin{array}{l}\text { WC-Ni pseudo alloy } \\
\text { CS6,CS14,CS20, }\end{array}$ & $\mathrm{H}_{2} \mathrm{SO}_{4}$ & $\mathrm{WO}_{3}$ & [12] \\
\hline 3 & $\begin{array}{l}\text { CS22 } \\
\text { WC scraps }\end{array}$ & $\mathrm{HCl} / \mathrm{Citric}$ acid & Co and $\mathrm{W}$ & [13] \\
\hline 4 & Tungsten Alloy & $\mathrm{NaOH}$ & $90 \%$ tungsten & [15] \\
\hline 5 & Tungsten & $\mathrm{NaOH}$ & Tungstate & [16] \\
\hline 6 & $\begin{array}{l}\text { Cemented tungstate } \\
\text { carbide }\end{array}$ & $\begin{array}{l}\text { Amm. hydroxide/ } \\
\text { Amm. chloride, } \\
\text { Amm. carbonate, } \\
\text { Amm. sulphate }\end{array}$ & $\begin{array}{l}\text { APT (Ammonium } \\
\text { paratungstate) }\end{array}$ & [18] \\
\hline 7 & $\begin{array}{l}\text { Tungsten carbide } \\
\text { scrap }\end{array}$ & Aqueous ammonia & Co metal and $\mathrm{WO}_{3}$ & [19] \\
\hline 8 & Tungsten alloy swarf & $\mathrm{NaOH}$ & $\begin{array}{l}\text { APT (Ammonium } \\
\text { paratungstate) }\end{array}$ & [20] \\
\hline 9 & $\begin{array}{l}\text { Hard metal content } \\
15 \mathrm{Wt} . \% \text { of binder }\end{array}$ & $\mathrm{HCl}$ & Co and W & [21] \\
\hline 10 & WC-6\% Co (VK-6) & $\mathrm{H}_{3} \mathrm{PO}_{4}$ & $\begin{array}{l}\text { Separation of Co } \\
\text { and WC phase }\end{array}$ & [22] \\
\hline 11 & $\begin{array}{l}\text { Cemented WC- } 87 \% \text {, } \\
\text { Co- } 13 \%\end{array}$ & $\mathrm{HNO}_{3}$ & $\mathrm{~W}$ and Co & [23] \\
\hline 12 & $\begin{array}{l}\text { Machine or Tool } \\
\text { grade WC }\end{array}$ & $\mathrm{H}_{2} \mathrm{SO}_{4}$ & Tungstic acid & [24] \\
\hline 13 & Heavy metal alloys & $\mathrm{NH}_{4} \mathrm{OH} / \mathrm{NH}_{4} \mathrm{NO}_{3}$ & $\begin{array}{l}\text { APT (Ammonium } \\
\text { paratungstate) }\end{array}$ & [25] \\
\hline 14 & $\begin{array}{l}\text { Sintered metal } \\
\text { carbide }\end{array}$ & $\mathrm{NaOH}$ & $\begin{array}{l}\text { WC powder and } \\
\text { Co }\end{array}$ & {$[26$} \\
\hline 15 & $\begin{array}{l}\text { Cemented tungsten } \\
\text { scrap }\end{array}$ & $\begin{array}{l}\mathrm{HCl} / \text { Chelating agent } \\
\text { (Citric acid) }\end{array}$ & $\begin{array}{l}\text { Separation of Co } \\
\text { and recover WC } \\
\text { powder }\end{array}$ & [27] \\
\hline 16 & $\begin{array}{l}\text { Scraps of sintered } \\
\text { metal carbide }\end{array}$ & $\mathrm{HNO}_{3}$ & Co and $\mathrm{W}$ & [28] \\
\hline 17 & WC-6\% Co alloy & $\mathrm{H}_{3} \mathrm{PO}_{4}$ & $\begin{array}{l}\text { Separation of Co; } \\
\text { WC powder }\end{array}$ & [29] \\
\hline 18 & Hard metal scrap & $10 \% \mathrm{HNO}_{3}$ & $\mathrm{WO}_{3}$ & [30] \\
\hline
\end{tabular}


In the last few decades, large numbers of a hydrometallurgical process with/without prior thermal oxidation have been explored using lixiviants such as $\mathrm{NaOH}$ and $\mathrm{HCl}$, to produce the tungsten trioxide $\left(\mathrm{WO}_{3}\right)$ and cobalt salts [5-9]. Direct leaching of WC scrap in an acidic medium seems to be quite promising;

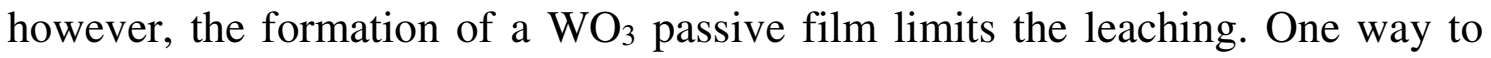
avoid passivation during acid leaching is to crush the WC scrap to particle sizes below a few hundred micrometers, which is again hardly possible for a hard metal scrap [10]. Contrastingly, thermal oxidation of WC consumes a huge amount of energy and hence, it is regarded as the main drawback of the process.

The latest trend in the WC scrap processing employs the selective electrochemical dissolution of cobalt binder in acid electrolytes, along with the oxidation of tungsten to $\mathrm{WO}_{3}$ [11-12]. Some of the electrochemical studies for the dissolution of WC are summarized in Table 1.

$\mathrm{H}_{3} \mathrm{PO}_{4}, \mathrm{H}_{2} \mathrm{SO}_{4}, \mathrm{HCl}$ and $\mathrm{HNO}_{3}$ based electrolytes effectively dissolve WC. However, the downside of using the acid electrolyte is the formation of insoluble tungstic acid at the dissolution sites, which reduces the rate of dissolution [1314]. The electrochemical processing of tungsten in a sodium hydroxide electrolyte also accounts for a similar behavior, owing to the presence of $\mathrm{Co}(\mathrm{OH})_{\mathrm{x}}{ }^{\mathrm{n}+}$ passive films [15-16]. The alkaline medium actually accelerates the corrosion process of $\mathrm{WC}-\mathrm{Co}$, where $\mathrm{WC}$ dissolution occurs significantly at alkaline $\mathrm{pH}$ values [17].

Aqueous ammonia is widely used to manufacture ammonium paratungstate which undergoes a sintering process with carbon to manufacture the WC tool components. Ammoniacal lixiviants were also tested for the production of ammonium paratungstate from WC scrap [18]. Thermodynamic calculation shows that aqueous ammonium forms soluble compounds with both $\mathrm{W}$ and Co (Fig. 1).
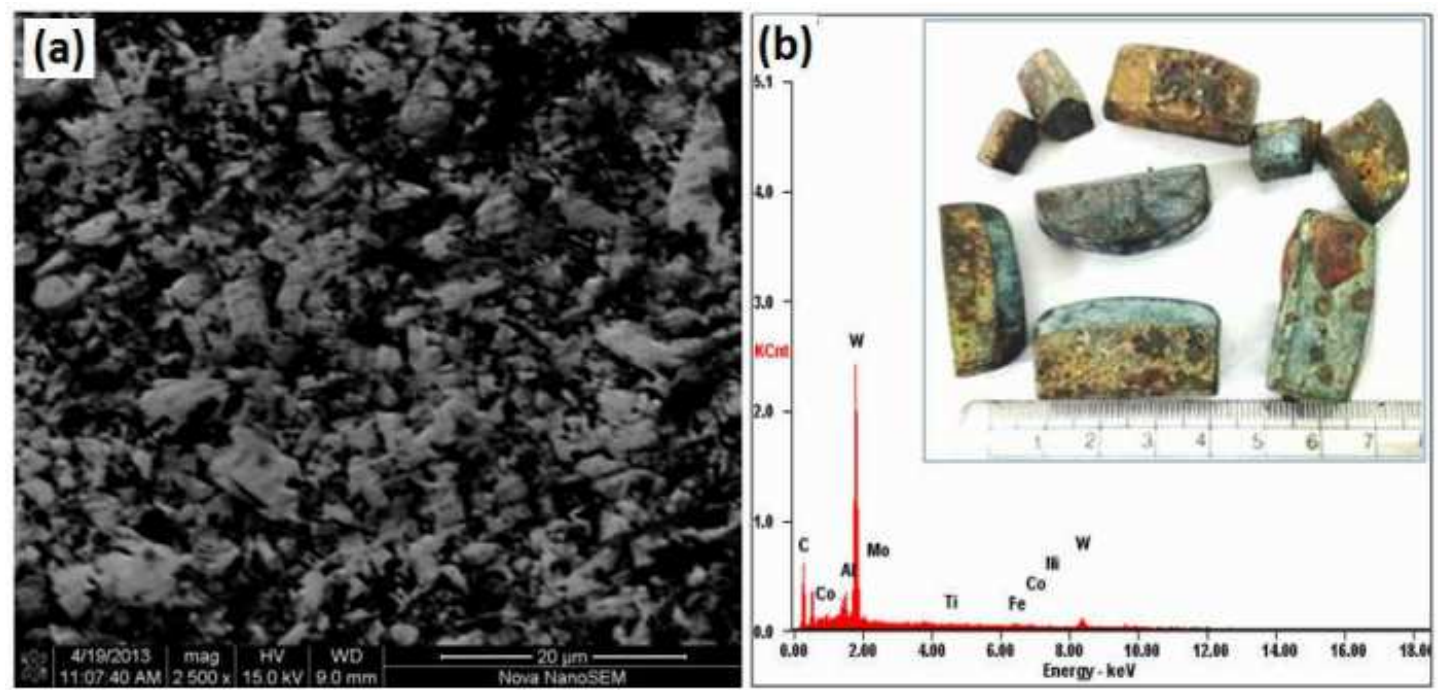

Figure 1. (a) FE-SEM micrograps of WC-Co materials; (b) shows the image of corresponding EDX results, and inset in image (b) shows the digital image of WC-10Co samples used in the present studies. 
Ammonia-based electrolytes can be considered a promising medium for electrochemical dissolution of WC-Co hard scraps.

Previous work by the authors has also shown the advantage of ammoniacal media to avoid passivation problems observed in a hydrochloric acid medium for the dissolution of WC scrap [19]. Herein, the electrochemical dissolution behavior of WC scrap material in the ammoniacal media studied by linear sweep voltammetry is reported. Anodic polarization curves in varying electrolyte compositions were obtained. The effect of ammonium salts was examined on the basis of current density and other parameters. The role of ammonium salts in the dissolution of WC-Co is corroborated by microscopic examinations and quantitative analysis.

\section{Experimental \\ Materials}

Cemented tungsten carbide (WC-10Co) tool scrap material was obtained from a local scrap dealer (an image of the sample is shown in Fig. 1). The analytical reagent (AR) grade, ammonium chloride $\left(\mathrm{NH}_{4} \mathrm{Cl}\right)$, ammonium sulphate $\left(\left(\mathrm{NH}_{4}\right)_{2} \mathrm{SO}_{4}\right)$, ammonium carbonate $\left(\left(\mathrm{NH}_{4}\right)_{2} \mathrm{CO}_{3}\right)$ and aqueous ammonia $(25 \%)$ were obtained from Merck Specialties Private Limited, Mumbai. ASTM grade I water was used for all the solutions preparation and samples cleaning work. The chemical composition of the WC-10Co scrap sample was determined by standard methods [31].

\section{Potentiodynamic experiments}

A GamryEchem Analyst potentiostat was used for polarization studies. The experimental setup consisted of a three electrode cell which had a working electrode (WC-10Co sample), a platinum counter electrode of $1 \mathrm{~cm}^{2}$ area and a saturated calomel electrode (SCE). The working cell was filled with the fresh electrolyte $(100 \mathrm{~mL})$ for each polarization experiment. The WC-10Co sample was coated with an inert resin, and the exposed surface area of the sample was 1 $\mathrm{cm}^{2}$. Prior to each experiment, the sample was polished to produce a new surface with the help of grit paper (up to 1200 grit size) and a polishing disc, and rinsed with deionized water. For the polarization scan, the potential was applied at a scan rate of $5 \mathrm{mV} / \mathrm{s}$ from $-1.5 \mathrm{~V}_{\mathrm{SCE}}$ to $7 \mathrm{~V}_{\mathrm{SCE}}$, at room temperature. Initially, polarization scans using different dilutions of ammonia (50-150 g/L) were carried out. Ammonium salts viz. $\mathrm{NH}_{4} \mathrm{Cl},\left(\mathrm{NH}_{4}\right)_{2} \mathrm{SO}_{4}$ and $\left(\mathrm{NH}_{4}\right)_{2} \mathrm{CO}_{3}$ were mixed in the $150 \mathrm{~g} / \mathrm{L}$ of ammonia solution to find out the suitable additive. Separate scans were also carried out with different concentrations of the most suitable salt mixed in $150 \mathrm{~g} / \mathrm{L}$ of ammonia solution.

\section{Characterization of samples}

The polarized samples were examined using a metallurgical microscope (LEICA DM6000BM) to examine the morphological alteration after a polarization scan. The air-dried samples were mounted in a cold setting resin and examined under the optical microscope. About 50 images at varying z-axis were snapped in multifocal mode and merged to generate a 3-dimensional image. Field Emission 
Scanning Electron Microscope (FE-SEM, FEI Nova NanoSEM 320) coupled with EDX was employed to examine the surface morphology and to determine the association of different elements at selected points on the reacted surface of the working electrode, i.e. WC-10Co.

\section{Results and discussion}

The FE-SEM image of the WC-Co scrap sample is shown in Fig. 1. Mainly two types of phases, i.e., grey colored tungsten carbide and black colored cobalt (matrix) containing tungsten carbide, are observed. The EDX analysis also confirmed the presence of other impurity elements viz. Fe, Al, Mo, Ti, Ni, etc. in trace amount, as also obtained by the chemical analysis of WC scrap samples. The chemical composition of WC-10Co scrap sample is given in Table 2. Usually, tungsten (W), cobalt (Co) and carbon (C) are the major constituents in the WC-10Co. The impurities viz. Al, Ti, Mo are also present in trace amount.

Table 2. Chemical composition of the WC-10Co sample.

\begin{tabular}{lcccrccc}
\hline Element & $\mathrm{W}$ & $\mathrm{C}$ & $\mathrm{Co}$ & $\mathrm{Fe}$ & $\mathrm{Al}$ & $\mathrm{Ti}$ & $\mathrm{Mo}$ \\
\hline Wt.\% & 81.23 & 5.20 & 10.15 & 0.98 & 0.06 & 0.005 & 0.007 \\
\hline
\end{tabular}

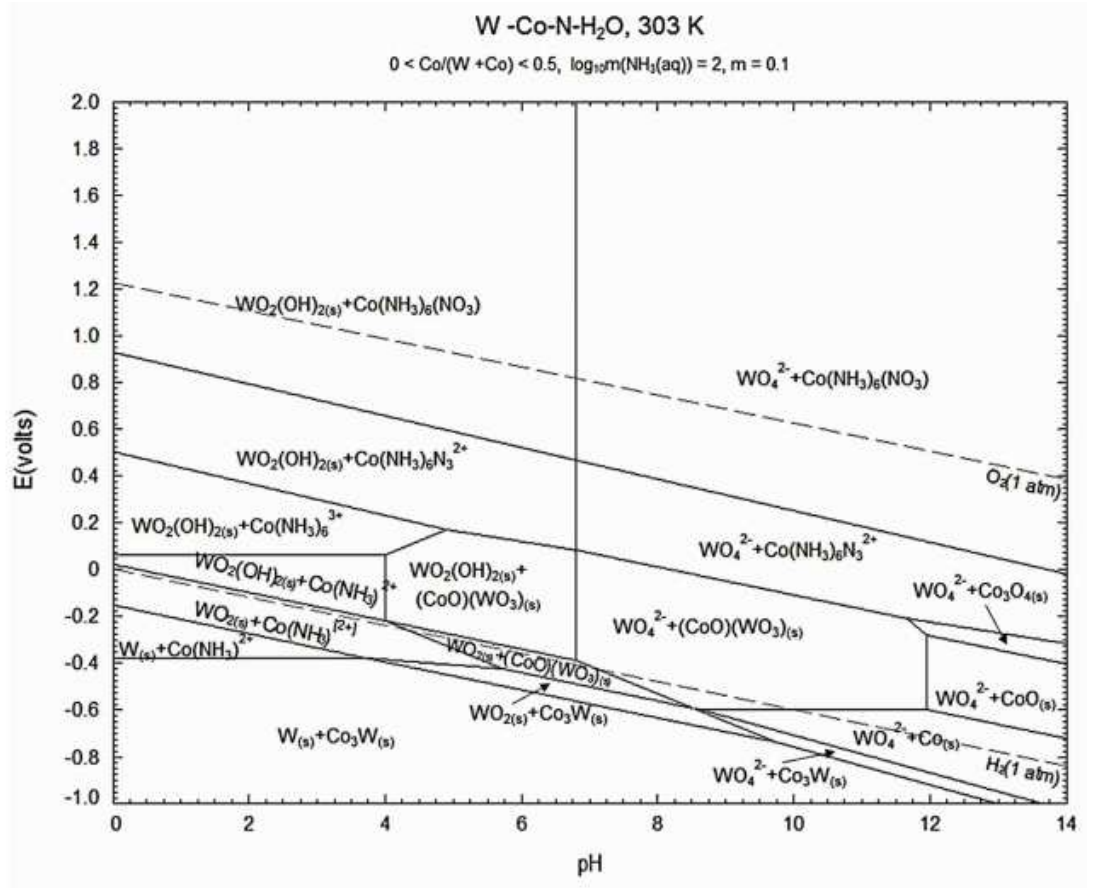

Figure 2. Potential-pH diagram of $\mathrm{W}-\mathrm{Co}-\mathrm{N}-\mathrm{H}_{2} \mathrm{O}$ system.

Prior to the electrochemical tests, thermodynamic modeling of tungsten and cobalt was carried out to understand the WC-Co- $\mathrm{NH}_{3}-\mathrm{H}_{2} \mathrm{O}$ system using FactSage thermochemical software V-6.4. Fig. 2 shows the $\mathrm{pH}$-potential diagram where the stability of various ionic species and complexes formed by $\mathrm{W}$ and $\mathrm{Co}$ in aqueous ammonia is denoted. Apparently, tungsten forms tungstate ions $\left(\mathrm{WO}_{4}{ }^{2-}\right)$ upon oxidation in an ammoniacal solution. On the other hand, cobalt 
forms complex ions in which ammonia acts as a ligand to form octahedral complexes.

In the electrochemical dissolution of $\mathrm{WC}-10 \mathrm{Co}$, and during its progress through corrosion/oxidation processes at an anode-electrolyte interface, it was shown that the $\mathrm{pH}$ of the solution greatly influences the surface oxidation tendency of WC [32]. The oxidation of WC in an acidic solution proceeds through Eq. (1)

$$
\mathrm{WC}+5 \mathrm{H}_{2} \mathrm{O} \rightarrow \mathrm{WO}_{3}+\mathrm{CO}_{2}+10 \mathrm{H}^{+}+10 \mathrm{e}^{-}
$$

The $\mathrm{WO}_{3}$ layer protects the WC surface from further corrosion, resulting in a lower current density [33]. In contrast, neutral to alkaline solutions promote $\mathrm{W}$ oxidation by forming $\mathrm{WO}_{4}{ }^{2-}$ in a constant cycle of oxidation and dissolution. The surface of WC dissolves as tungstate ions, according to Eq. (2). When there is an ammoniacal solution, the tungstate ion reacts with $\mathrm{NH}_{4}{ }^{+}$ion and remains soluble, as shown in Eq. (3):

$$
\begin{array}{r}
\mathrm{WC}+14 \mathrm{OH}^{-} \rightarrow \mathrm{WO}_{4}{ }^{2-}+\mathrm{CO}_{3}{ }^{2-}+7 \mathrm{H}_{2} \mathrm{O}+10 \mathrm{e}^{-} \\
\mathrm{WO}_{4}{ }^{2-}+2 \mathrm{NH}_{4}{ }^{+} \rightarrow\left(\mathrm{NH}_{4}\right)_{2} \mathrm{WO}_{4}
\end{array}
$$

The $\mathrm{WO}_{4}{ }^{2-}$ ions are thermodynamically stable (Fig. 2) above $\mathrm{pH} 7$, throughout the applied potential range; hence, reaction (3) should proceed actively in the ammoniacal medium. On the other hand, the dissolution of cobalt takes place by oxidation to generate $\mathrm{Co}^{2+}$, followed by dissolution in the acidic solution [17]. In general, cobalt gets passivated in alkaline solutions, forming Co-hydroxides and impeding further oxidation [34]. However, the ammonical solution should facilitate the oxidation of $\mathrm{Co}$ to $\mathrm{Co}^{2+}$ by forming a stable complex, according to the Eqs. (4-5).

$$
\begin{gathered}
\mathrm{Co} \rightarrow \mathrm{Co}^{2+}+2 \mathrm{e}^{-} \\
\mathrm{Co}^{2+}+6\left[\mathrm{NH}_{3}\right]_{\mathrm{aq}}+2 \mathrm{OH}^{-} \rightarrow\left[\mathrm{Co}\left(\mathrm{NH}_{3}\right)_{6}\right](\mathrm{OH})_{2}
\end{gathered}
$$

Electrochemically, the oxidative dissolution of WC-10Co begins at the corrosion potential $\left(\mathrm{E}_{\mathrm{corr}}\right)$ or open circuit potential (OCP). Hence, it is a critical parameter, as it optimizes the composition of an electrolyte. Higher values of OCP indicate high resistance to electrochemical dissolution or corrosion [17, 35]. Another factor is the magnitude of pseudo-passivation observed in Co-based cemented carbide materials. The pseudo-passivation diminishes the anodic current densities [36-37]. Therefore, the anodic current density, OCP and the over-potential to surpass the pseudo-passivation area in the polarization curves are the important parameters to arrive at an optimal electrolyte composition.

\section{Polarization of $\mathrm{WC}$-10Co in $\mathrm{NH}_{3}-\mathrm{H}_{2} \mathrm{O}$}

The characteristic anodic plots shown in Fig. 3 represent the magnitude of active, passive and trans-passive regions as a function of the concentration of ammonia, i.e., $\left[\mathrm{NH}_{3}\right]$. The maximum current density $\left(\mathrm{i}_{\mathrm{a}}\right)$ at the transpassive region is very 
significant from the corrosion (electrodissolution) point of view. General features of potentiodynamic polarization curves are summarized in Table 3. An inverse relationship between the concentration of ammonia and OCP is evident from the data. This signifies that WC-10Co becomes less noble when ammonia concentration is increased and hence, more susceptible to electrochemical dissolution. Nevertheless, the dissolution tendency in terms of $i_{a}\left(45.33 \mathrm{~mA} / \mathrm{cm}^{2}\right.$ for $50 \mathrm{~g} / \mathrm{L}, 37.94 \mathrm{~mA} / \mathrm{cm}^{2}$ for $100 \mathrm{~g} / \mathrm{L}$ and $33.08 \mathrm{~mA} / \mathrm{cm}^{2}$ for $150 \mathrm{~g} / \mathrm{L}$ ammonia, respectively) is much smaller than that reported for acidic as well as $\mathrm{NaOH}$ based electrolytes [36, 38]. Feeble current density in the ammoniacal solution is attributed to the strong chemisorption of ammonia and $\mathrm{OH}^{-}$radicals, taking part in the passivation of the metal surface [39]. Investigations by Vooys et al. (2001) established a mechanism that included the adsorption of $\mathrm{NH}_{3}$ over $5 \mathrm{~d}$ metals (Ir and $\mathrm{Pt}$ ) and oxidation to $\mathrm{N}_{2}$ via the formation of $\mathrm{NH}_{2}, \mathrm{NH}$ intermediates. The analogous behavior may be expected with $\mathrm{W}$, a $5 \mathrm{~d}$ metal.

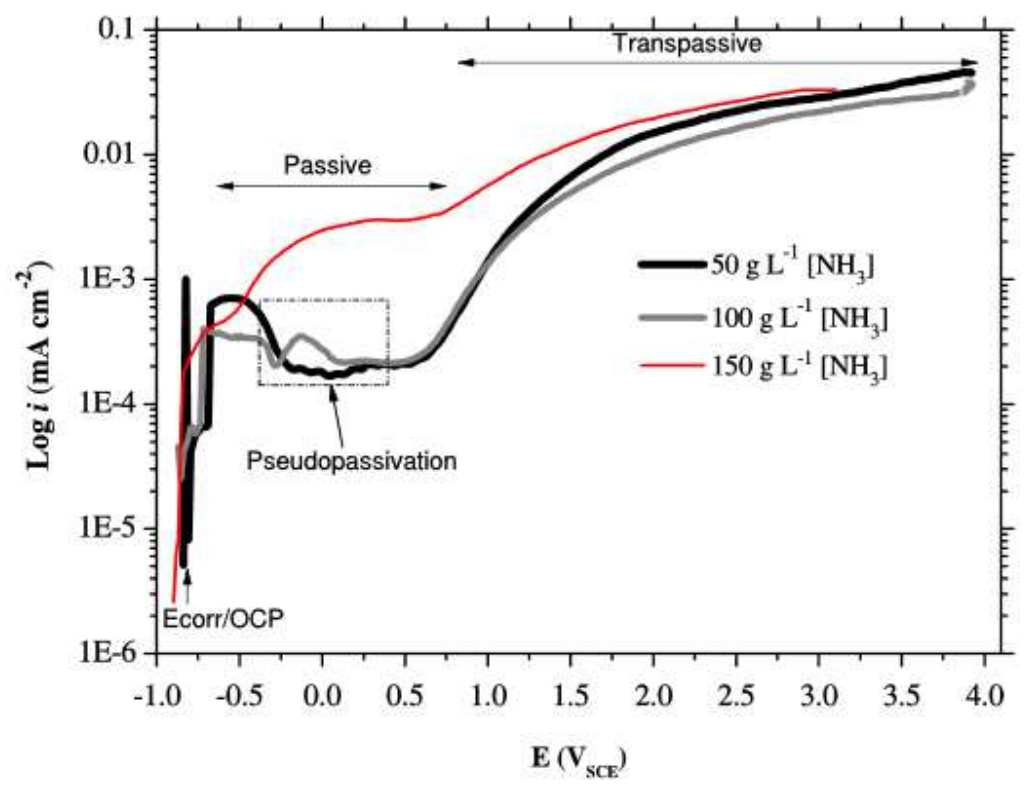

Figure 3. Potentiodynamic polarization plots of $\mathrm{WC}-10 \mathrm{Co}$ in the different ammonia concentrations.

As demonstrated earlier by the authors [19], an ammoniacal solution has an advantage over acidic media, because $\mathrm{WO}_{3}$ formed by oxidation remains unstable and undergoes chemical dissolution as per reaction (3). However, intermittent passivation cannot be avoided in the anodic curves. A study on the polarization behavior of tungsten in $0.1 \mathrm{M} \mathrm{K}_{2} \mathrm{SO}_{4}$ found the pseudo-plateau regions in the anodic curve, which was attributed to the reduction of current [38]. In our studies, the anodic curves (Fig. 3) depict pseudo-passivation at low concentrations of ammonia, particularly for 50 and $100 \mathrm{~g} / \mathrm{L}$ of ammonia solutions. The inconsistent passive film over WC-10Co redissolved at an increased potential $\left(>0.500 \mathrm{mV}_{\mathrm{SCE}}\right)$. The magnitude of the pseudo-passive region is about $772.1 \mathrm{mV}_{\mathrm{SCE}}$ and $730.4 \mathrm{mV}_{\mathrm{SCE}}$ for $50 \mathrm{~g} / \mathrm{L}$ and $100 \mathrm{~g} / \mathrm{L}$ of ammonia, respectively, but negligibly small when $150 \mathrm{~g} / \mathrm{L}$ of ammonia were employed. 
Table 3. Electrochemical parameters determined in polarization scans of WC-10Co in ammoniacal media.

\begin{tabular}{|c|c|c|c|c|}
\hline $\begin{array}{l}{\left[\mathrm{NH}_{3}\right]} \\
(\mathrm{g} / \mathrm{L})\end{array}$ & $\begin{array}{c}\text { Type of additive and } \\
\text { quantity } \\
(\mathrm{w} / \mathrm{v})\end{array}$ & 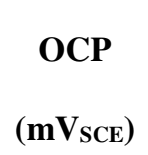 & $\begin{array}{l}\text { Anodic current } \\
\text { density, } i_{a} \\
\left(\mathbf{m A} / \mathbf{c m}^{2}\right)\end{array}$ & $\begin{array}{c}\text { Passive } \\
\text { range/overvoltage } \\
\left(\mathrm{mV}_{\mathrm{SCE}}\right)\end{array}$ \\
\hline 50 & - & -824.2 & 45.28 & 772.1 \\
\hline 100 & - & -854.3 & 37.76 & 730.4 \\
\hline 150 & - & -884.1 & 32.83 & 255.0 \\
\hline 150 & $1 \%\left(\mathrm{NH}_{4}\right)_{2} \mathrm{SO}_{4}$ & -779.1 & 352.4 & 670.6 \\
\hline 150 & $1 \%\left(\mathrm{NH}_{4}\right)_{2} \mathrm{CO}_{3}$ & -719.2 & 294.4 & 715.6 \\
\hline 150 & $1 \% \mathrm{NH}_{4} \mathrm{Cl}$ & -795.3 & 543.7 & 430.8 \\
\hline 150 & $5 \% \mathrm{NH}_{4} \mathrm{Cl}$ & -659.2 & 819.1 & 311.8 \\
\hline 150 & $10 \% \mathrm{NH}_{4} \mathrm{Cl}$ & -644.4 & 819.1 & 700.3 \\
\hline
\end{tabular}

This substantiates the improvement in the oxidation of WC-10Co upon increasing the concentration of ammonia, certainly by the conversion of $\mathrm{W}$ and Co into corresponding soluble species, according to Eqs. (2-5). The dependence of the electro-dissolution tendency of tungsten was found on the diffusion of $\mathrm{OH}^{-}$ ions in a strong alkaline solution [38]. Similar behavior may be presumed responsible by the $150 \mathrm{~g} / \mathrm{L}$ ammonia on the surface of WC-10Co.

\section{Effect of $\mathrm{Cl}^{-} \mathrm{SO}_{4}^{2-}$ and $\mathrm{CO}_{3}^{2-}$ ions}

Polarization curves for $150 \mathrm{~g} / \mathrm{L}$ ammonia with $\mathrm{Cl}^{-}, \mathrm{SO}_{4}{ }^{2-}$ and $\mathrm{CO}_{3}{ }^{2-}$ additive anions (supplied by an addition of $1 \% \mathrm{w} / \mathrm{v} \mathrm{NH} 4 \mathrm{Cl},\left(\mathrm{NH}_{4}\right)_{2} \mathrm{SO}_{4}$ and $\left(\mathrm{NH}_{4}\right)_{2} \mathrm{CO}_{3}$, separately) are illustrated in Fig. 4. The enhanced anodic current as shown in Fig. 4 can be attributed to the corrosive behavior of $\mathrm{Cl}^{-}, \mathrm{SO}_{4}{ }^{2-}$ and $\mathrm{CO}_{3}{ }^{2}$, as indicated by corresponding current densities. The corresponding reactions can be represented by Eqs. (6-8):

$$
\begin{array}{r}
\mathrm{Co}^{2+}+2 \mathrm{Cl}^{-}+6 \mathrm{NH}_{3} \rightarrow\left[\mathrm{Co}\left(\mathrm{NH}_{3}\right)_{6}\right] \mathrm{Cl}_{2} \\
\mathrm{Co}^{2+}+\mathrm{SO}_{4}{ }^{2-}+6 \mathrm{NH}_{3} \rightarrow\left[\mathrm{Co}\left(\mathrm{NH}_{3}\right)_{6}\right] \mathrm{SO}_{4} \\
\mathrm{Co}^{2+}+\mathrm{CO}_{3}^{2-}+6 \mathrm{NH}_{3} \rightarrow\left[\mathrm{Co}\left(\mathrm{NH}_{3}\right)_{6}\right] \mathrm{CO}_{3}
\end{array}
$$

The role of such ions in the aqueous corrosion of several metals has been studied before $[3,11,13,33]$. These ions have been found significantly affecting the corrosion behavior of the studied metal. For example, an accelerated corrosion of cobalt in the hard metal matrix corresponds to the increase in current density by the order of 10 , even in the presence of a small concentration of $\mathrm{Cl}^{-}$ions (100 $\mathrm{mg} / \mathrm{L})$ [39]. The low current density in $150 \mathrm{~g} / \mathrm{L}$ ammonia increased significantly to $543.7 \mathrm{~mA} / \mathrm{cm}^{2}$ in the presence of $\mathrm{Cl}^{-}$ions, and with $\mathrm{SO}_{4}{ }^{2-}$ and $\mathrm{CO}_{3}{ }^{2-}$ rose to $352.4 \mathrm{~mA} / \mathrm{cm}^{2}$ and $294.4 \mathrm{~mA} / \mathrm{cm}^{2}$, respectively. In addition to this, OCP moved to more negative values, i.e., $-795 \mathrm{mV}_{\mathrm{SCE}}$, after the addition of $\mathrm{NH}_{4} \mathrm{Cl}$, as compared to $\left(\mathrm{NH}_{4}\right)_{2} \mathrm{SO}_{4} \quad\left(-779.1 \quad \mathrm{mV}_{\mathrm{SCE}}\right)$ and $\left(\mathrm{NH}_{4}\right)_{2} \mathrm{CO}_{3} \quad\left(-719.2 \quad \mathrm{mV}_{\mathrm{SCE}}\right)$ additions. 


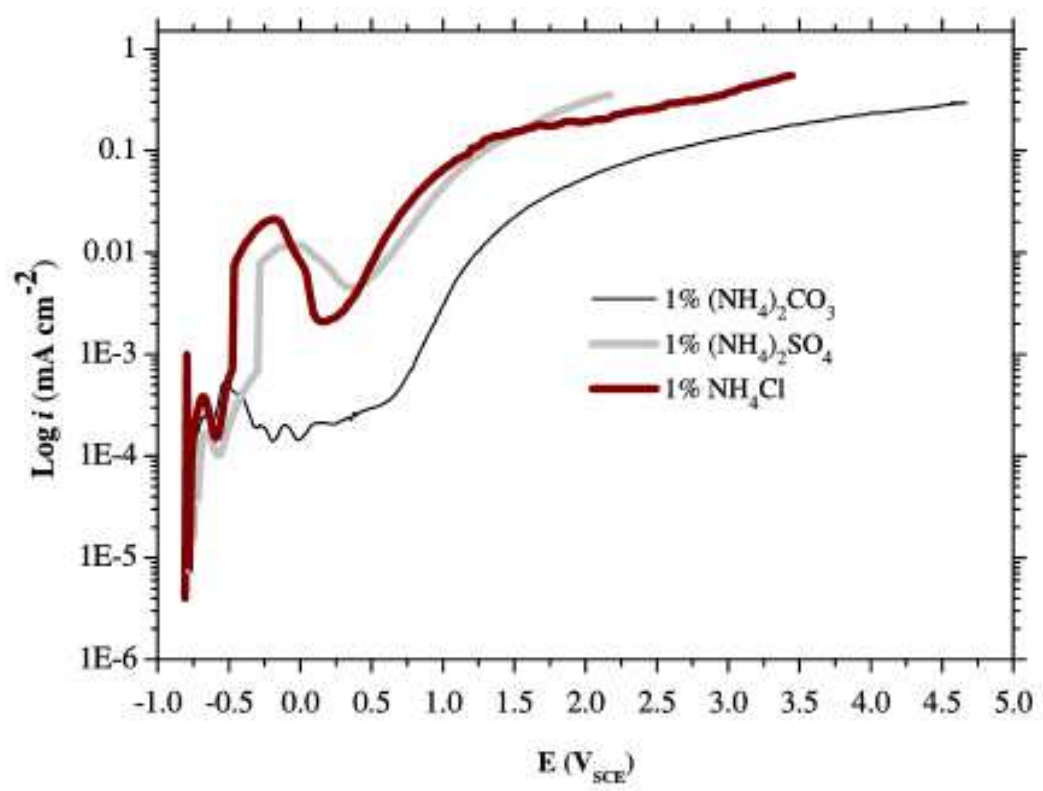

Figure 4. Effect of $\mathrm{NH}_{4} \mathrm{Cl}$, $\left(\mathrm{NH}_{4}\right)_{2} \mathrm{SO}_{4}$ and $\left(\mathrm{NH}_{4}\right)_{2} \mathrm{CO}_{3}$ on polarization behavior of WC$10 \mathrm{Co}$.

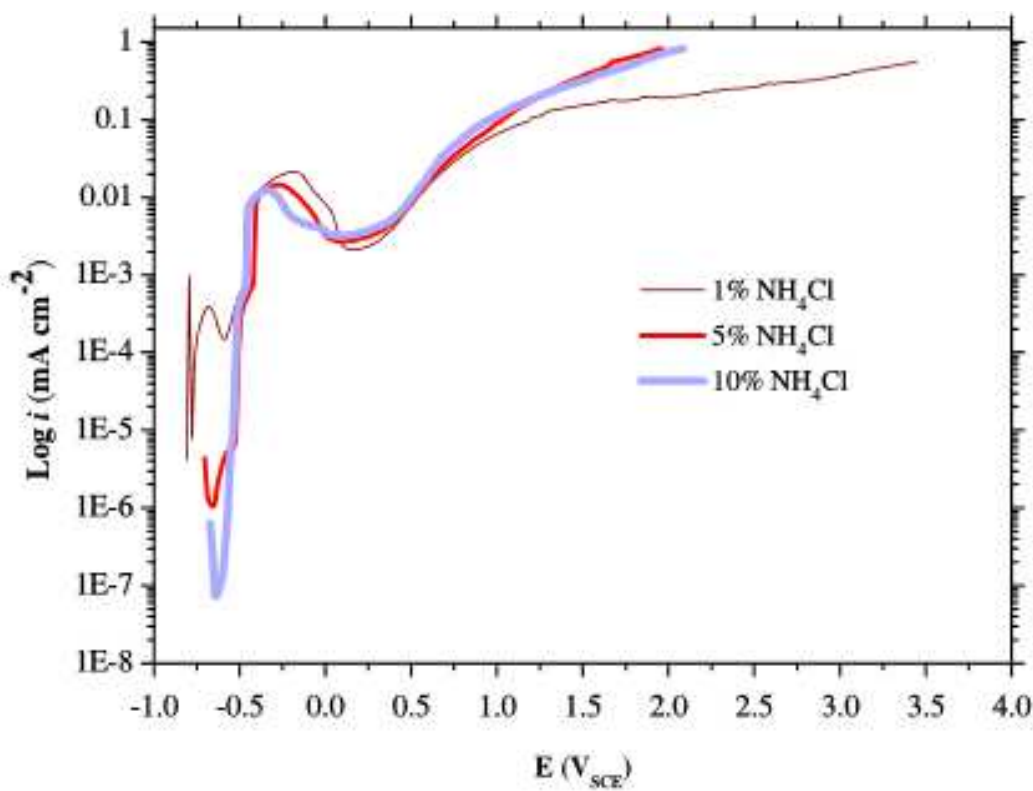

Figure 5. Effect of the concentration of $\mathrm{NH}_{4} \mathrm{Cl}$ in a $150 \mathrm{~g} / \mathrm{L}$ ammonia solution on the polarization behavior of WC-10Co.

This demonstrates the less noble nature of $\mathrm{WC}-10 \mathrm{Co}$ in the presence of $\mathrm{Cl}^{-}, \mathrm{SO}_{4}{ }^{2-}$ and $\mathrm{CO}_{3}{ }^{2-}$. Evidently, $\mathrm{NH}_{4} \mathrm{Cl}$ supports the $\mathrm{WC}-10 \mathrm{Co}$ dissolution more effectively than $\left(\mathrm{NH}_{4}\right)_{2} \mathrm{CO}_{3}$ and $\left(\mathrm{NH}_{4}\right)_{2} \mathrm{SO}_{4}$ in a $150 \mathrm{~g} / \mathrm{L}$ ammonia solution. As mentioned before, pseudo-passivation is not observed in $150 \mathrm{~g} / \mathrm{L}$ ammonia, but S-type pseudo-passive portions appeared in the anodic curves, in the presence of $\mathrm{Cl}^{-}$, $\mathrm{SO}_{4}{ }^{2-}$ and $\mathrm{CO}_{3}{ }^{2-}$ (Fig. 4). Herein, the overvoltage demand to alleviate the pseudopassivation is lowest (i.e., $430.8 \mathrm{mV}$ SCE) in the presence of $\mathrm{Cl}^{-}$ions, in comparison with $\mathrm{SO}_{4}{ }^{2-}$ and $\mathrm{CO}_{3}{ }^{2-}$ ions (Table 3 ).

The increase in $\mathrm{NH}_{4} \mathrm{Cl}$ addition improves the anodic polarization of WC-10Co (shown in Fig. 5). The addition of $5 \%(\mathrm{w} / \mathrm{v}) \mathrm{NH}_{4} \mathrm{Cl}$ enhanced the $\mathrm{i}_{\mathrm{a}}$ to 819.1 $\mathrm{mA} / \mathrm{cm}^{2}$ at $1.97 \mathrm{~V}_{\mathrm{SCE}}$. Further addition of $\mathrm{NH}_{4} \mathrm{Cl}$ does not affect $\mathrm{i}_{\mathrm{a}}$, achieved at 
relatively higher potential. OCP also follows the similar trend that increases from $-795 \mathrm{mV}_{\mathrm{SCE}}\left(1 \% \mathrm{w} / \mathrm{v} \mathrm{NH} \mathrm{NCl}_{4}\right)$ to $-659 \mathrm{mV}_{\mathrm{SCE}}(5 \% \mathrm{w} / \mathrm{v} \mathrm{NH} 4 \mathrm{Cl})$, and then slightly decreases to $-644.4 \mathrm{mV}_{\mathrm{SCE}}$ with $10 \%(\mathrm{w} / \mathrm{v}) \mathrm{NH}_{4} \mathrm{Cl}$. As a result, the $5 \%(\mathrm{w} / \mathrm{v})$ $\mathrm{NH}_{4} \mathrm{Cl}$ in the $150 \mathrm{~g} / \mathrm{L}$ ammonia solution emerges as the most suitable electrolyte.

\section{Microscopic examination of polarized WC-10Co surface}

The polarized WC-10Co surface usually gets passivated or altered during anodic oxidation of $\mathrm{W}$ or Co. Those oxidation products, if insoluble, arrest the advance dissolution of W and Co [34-35]. The SEM images illustrated in Figs. 6(a), 7(a) and 8(a) show a distinct topography on the surface of the WC-10Co samples polarized in $\mathrm{NH}_{4} \mathrm{OH}-\mathrm{NH}_{4} \mathrm{Cl}, \quad \mathrm{NH}_{4} \mathrm{OH}-\left(\mathrm{NH}_{4}\right)_{2} \mathrm{SO}_{4}$ and $\mathrm{NH}_{4} \mathrm{OH}-\left(\mathrm{NH}_{4}\right)_{2} \mathrm{CO}_{3}$ solutions. Further investigations of the polarized samples of WC-10Co were carried out using the optical microscope and SEM-EDX to examine the elemental association and morphology of the corrosion products.

\section{Effect of $\mathrm{Cl}^{-}$ions}

WC-10Co treated in $\mathrm{NH}_{4} \mathrm{OH}-\mathrm{NH}_{4} \mathrm{Cl}$ shows high abundance of overgrowths scattered over the reacted surface, depicted in Fig. 6(a). A closer look reveals buttons like formations lying on the flat surface (Fig. 6b). The EDX analysis (Wt.\%) at different points [Fig. 6(b)] is given in Table 4.
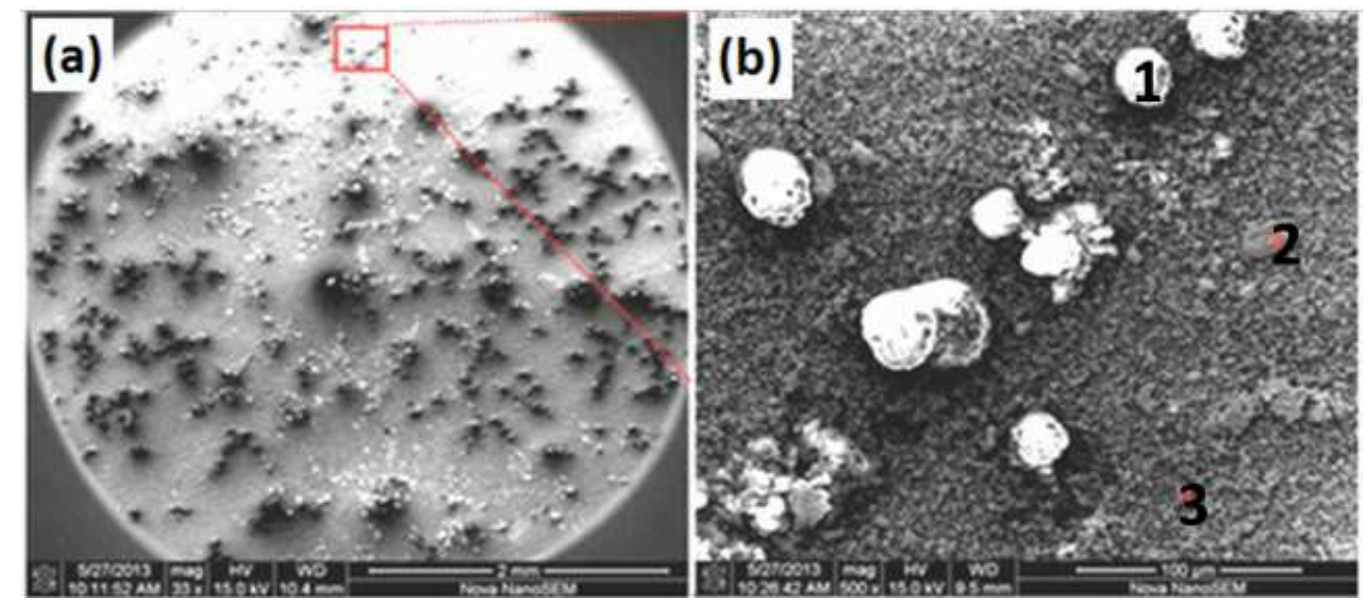

Figure 6. (a) SEM image of the $\mathrm{WC}-10 \mathrm{Co}$ sample polarized in a $\mathrm{NH}_{4} \mathrm{OH}-\mathrm{NH}_{4} \mathrm{Cl}$ solution, and (b) magnified view.

Interestingly, the $\mathrm{Cl}^{-}$ions mainly corrode the $\mathrm{Co}$ matrix, further improving the oxidation of $\mathrm{W}$, giving rise to a high anodic current. For instance, a higher concentration of $\mathrm{Co}$, along with the $\mathrm{Cl}$ at point 1 (Table 4 ) indicates a preferable attack of $\mathrm{Cl}^{-}$ions on $\mathrm{Co}$, and conversion into the soluble $\mathrm{Cl}^{-}$complexes.

The optical image of the surface (Fig. 7) shows a purple colored product lying on the surface. The 3-dimensional (3-d) image in Fig. 7 has mounds of Co salts grown (up to $30 \mu \mathrm{m}$ height) by oxidation of $\mathrm{Co}$ and protruding from underneath sites. In contrast, insoluble $\mathrm{CoO}$ could be the likely product in the absence of $\mathrm{Cl}^{-}$ ions [40]. Negligible oxygen concentration at point 1 (Table 4) confirms the absence of $\mathrm{CoO}$ passive film. Lower $\mathrm{W}$ content at point 1 denoted the preferable 
dissolution of $\mathrm{W}$, leaving immediately after the dissolution site; hence, point 1 represented the advanced stage of $\mathrm{W}$ and Co dissolution.

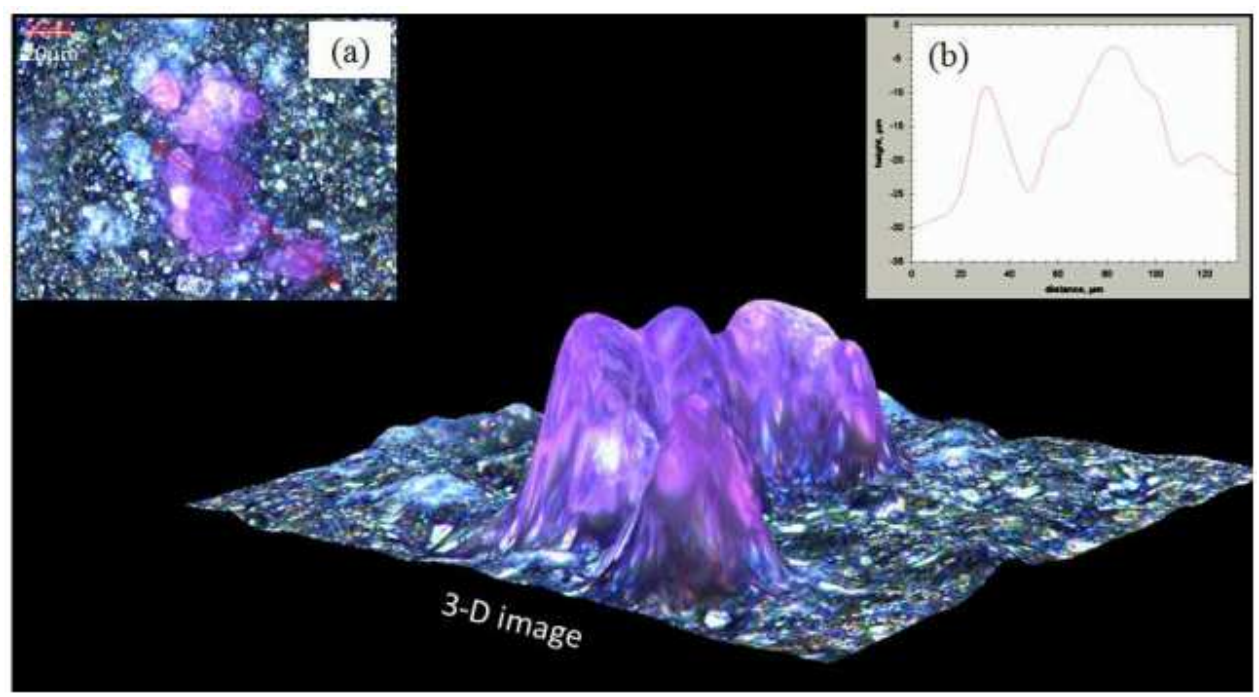

Figure 7. Optical microscopic investigation of WC-10Co sample polarized in $\mathrm{NH}_{4} \mathrm{OH}-$ $\mathrm{NH}_{4} \mathrm{Cl}$ solution, where, (a) optical image at 200x magnification, (b) depth profile of surface along the line marked in (a) and the 3-dimensional image at the center, are displayed.

Table 4. EDX analysis of points shown in Fig. 6(b).

\begin{tabular}{lllllll}
\hline \multirow{2}{*}{ Element } & \multicolumn{2}{c}{ Point - 1 } & \multicolumn{2}{c}{ Point - 2 } & \multicolumn{2}{c}{ Point - 3 } \\
\cline { 2 - 7 } & Wt. \% & At. \% & Wt. \% & At. \% & Wt. \% & At. \% \\
\hline C & 00.00 & 00.00 & 00.41 & 05.21 & 01.12 & 10.19 \\
N & 01.02 & 03.45 & 00.10 & 01.12 & 00.58 & 04.48 \\
O & 00.56 & 01.66 & 00.70 & 06.60 & 03.03 & 20.69 \\
Cl & 39.27 & 52.62 & 00.46 & 01.98 & 01.32 & 04.07 \\
Co & 49.29 & 39.73 & 02.21 & 05.70 & 03.84 & 07.11 \\
W & 09.86 & 02.55 & 96.12 & 79.40 & 90.11 & 53.46 \\
\hline
\end{tabular}

EDX analysis of point 2 represented an intermediate state of $\mathrm{W}$ and Co dissolution, where carbon has almost oxidized, and oxidation of $\mathrm{W}$ and chlorination of cobalt has just commenced (Table 4). On the other hand, high atomic percentage (At.\%) of $\mathrm{C}$ at point 3 in Fig. 6(b) represents an active surface of $\mathrm{WC}-10 \mathrm{Co}$ with adsorbed ammonia and $\mathrm{Cl}^{-}$. High At.\% of oxygen at point 3 also denoted the oxidation of $\mathrm{W}$ amenable to the dissolution by ammonia. Thus, the oxidizing nature of $\mathrm{Cl}^{-}$ions causes the high dissolution tendency of WC10Co, by eliminating the passive Co compound.

\section{Effect of $\mathrm{SO}_{4}^{2-}$ ions}

The WC-10Co surface polarized in $\mathrm{NH}_{4} \mathrm{OH}-\left(\mathrm{NH}_{4}\right)_{2} \mathrm{SO}_{4}$ solution obtains numerous scratch type formations (Figs. 8a-b). The EDX point analysis of Fig. $8(\mathrm{~b})$ is given in Table 5. 

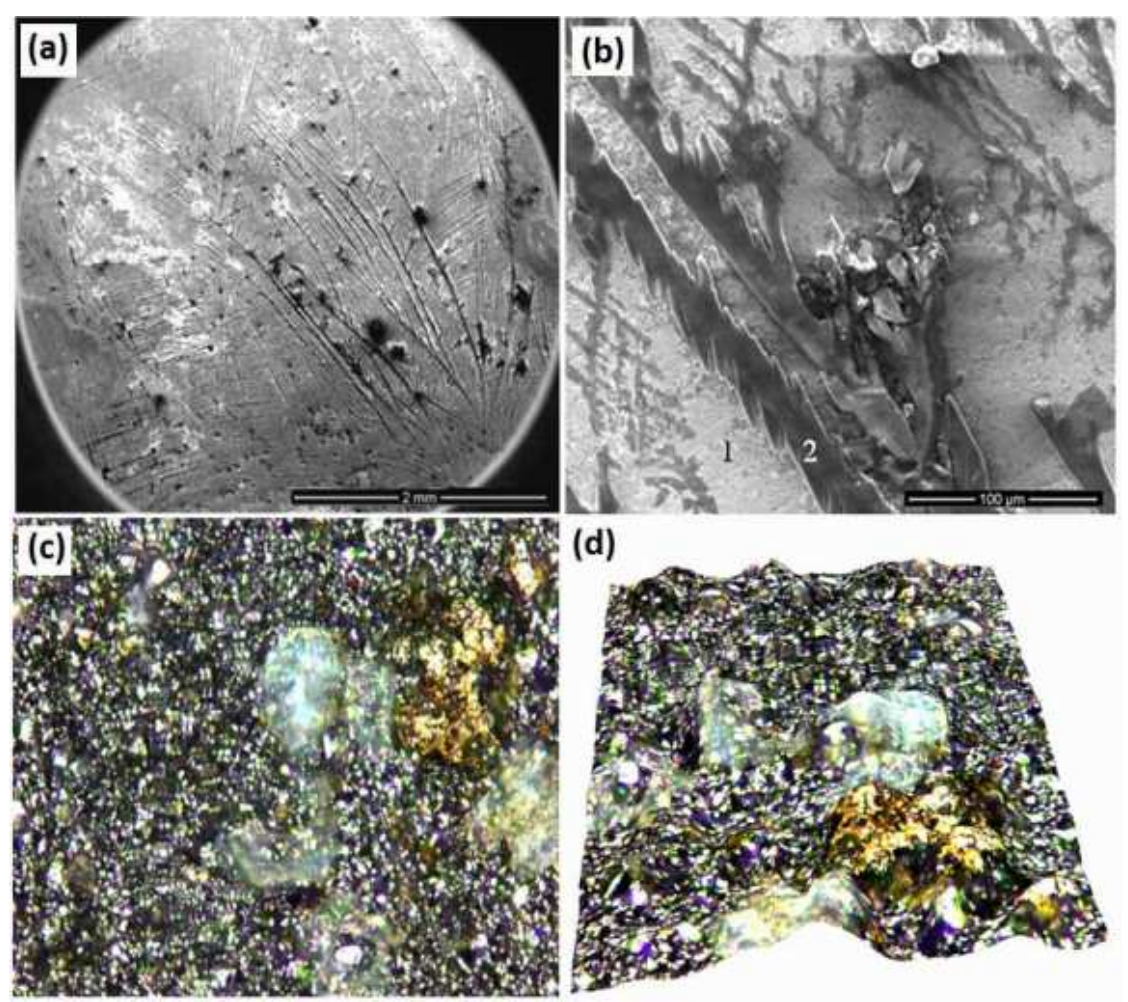

(d)

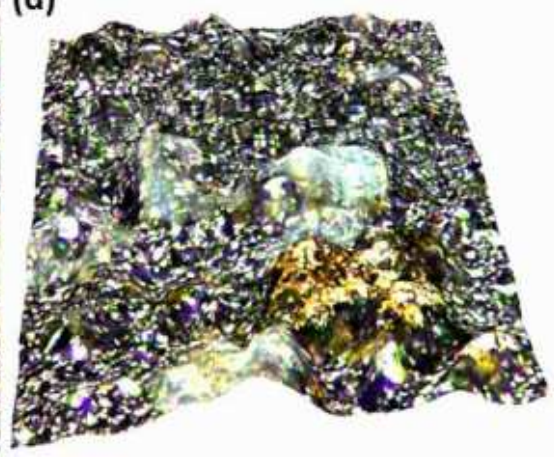

Figure 8. SEM and optical microscopic investigation of WC-10Co sample polarized in $\mathrm{NH}_{4} \mathrm{OH}-\left(\mathrm{NH}_{4}\right)_{2} \mathrm{SO}_{4}$ solutions: (a) SEM image of the reacted surface, (b) magnified view, (c) optical image at 200x magnification and (d) 3-dimensional image.

According to the EDX analysis, point 1 represents the active or unpassivated surface of the sample, whereas point 2 at the scratch like deposits indicates the simultaneous oxidation of $\mathrm{W}$ and Co. In addition, the significant concentration of sulfur at point 1 also indicates the presence of sulfate complexes of $\mathrm{Co}$.

Table 5. EDX analysis of points shown in Fig. 8(b).

\begin{tabular}{lllll}
\hline \multirow{2}{*}{ Element } & \multicolumn{2}{c}{ Point -1} & \multicolumn{2}{c}{ Point - 2 } \\
\cline { 2 - 5 } & Wt. \% & At. \% & Wt. \% & At. \% \\
\hline $\mathrm{C}$ & 01.32 & 15.12 & 00.31 & 01.05 \\
$\mathrm{~N}$ & 00.00 & 00.00 & 01.92 & 05.64 \\
$\mathrm{O}$ & 00.59 & 05.13 & 14.96 & 38.43 \\
$\mathrm{~S}$ & 00.51 & 02.21 & 23.27 & 29.84 \\
$\mathrm{Co}$ & 02.08 & 04.86 & 24.73 & 17.25 \\
$\mathrm{~W}$ & 95.28 & 71.55 & 34.81 & 07.78 \\
\hline
\end{tabular}

A comparatively lower concentration of $\mathrm{W}$ at point 2 has also accounted for its more preferable dissolution than that of cobalt. Optical image of the surface shows lustrous yellowish golden deposits (Fig. 8c).

Thus, it is evident from the EDX analysis that the dissolution of WC-10Co in $\mathrm{NH}_{4} \mathrm{OH}-1 \%\left(\mathrm{NH}_{4}\right)_{2} \mathrm{SO}_{4}$ routes occurred via the oxidation of $\mathrm{W}$ to the $\mathrm{WO}_{4}{ }^{2-}$, which dissolved in ammonia, and Co gets into the solution as sulfate complex. The presence of $\mathrm{SO}_{4}{ }^{2-}$ ions also activates the surface by reacting with insoluble passive films to form soluble films. 


\section{Effect of $\mathrm{CO}_{3}{ }^{2-}$ ions}

The SEM image of WC-10Co polarized in $\mathrm{NH}_{4} \mathrm{OH}-\left(\mathrm{NH}_{4}\right)_{2} \mathrm{CO}_{3}$ has tiny pits scattered on the reacted surface (Fig. 9a), however, not as abundant as those on the samples polarized in the presence of $\mathrm{Cl}^{-}$and $\mathrm{SO}_{4}{ }^{2-}$ ions.

The dark areas in the magnified image (Fig. 9b) represent the pits observed at low magnification in Fig. 9(a).

The EDX analyses of these magnified pits (point 1and 2 in Fig. 9b) are given in Table 6.

Table 6. EDX analysis of points shown in Fig. 9(b) and (c).

\begin{tabular}{lcrrrrrrrr}
\hline \multirow{2}{*}{ Element } & \multicolumn{2}{c}{ Point - 1 (11b) } & \multicolumn{2}{c}{ Point - 2 (11b) } & \multicolumn{2}{c}{ Point - 1 (11c) } & \multicolumn{2}{c}{ Point - 2 (11c) } \\
\cline { 2 - 9 } & \multicolumn{1}{c}{ Wt. \% } & At. \% & Wt. \% & At. \% & At. \% & At. \% & Wt. \% & \multicolumn{1}{c}{ At. \% } \\
\hline C & 06.12 & 25.09 & 39.53 & 64.82 & 01.12 & 12.54 & 01.13 & 05.50 \\
N & 00.67 & 02.35 & 05.06 & 07.12 & 00.00 & 00.00 & 00.29 & 01.22 \\
O & 01.86 & 05.72 & 10.78 & 13.27 & 00.38 & 03.23 & 01.45 & 05.28 \\
Co & 73.40 & 61.30 & 38.80 & 12.97 & 07.32 & 16.70 & 83.83 & 82.98 \\
W & 17.43 & 04.67 & 03.65 & 00.39 & 90.96 & 66.48 & 12.82 & 04.07 \\
\hline
\end{tabular}

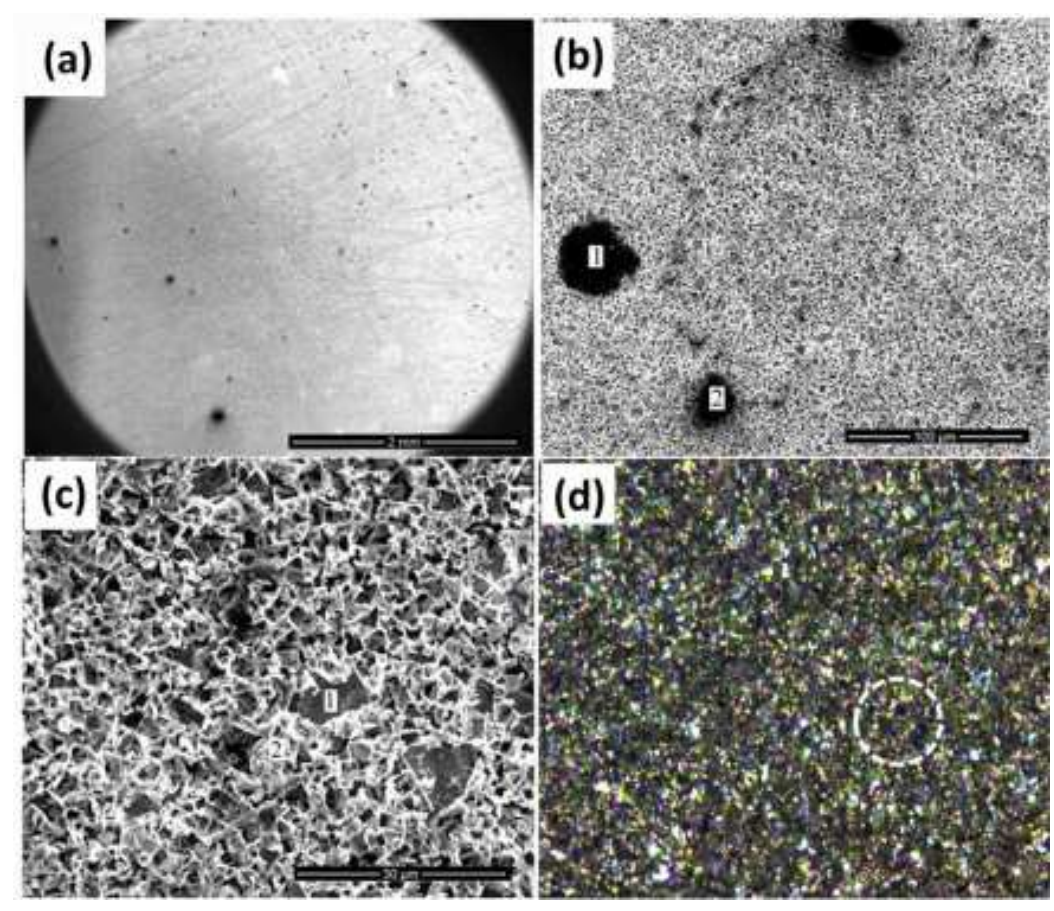

Figure 9. SEM and optical microscopic investigation of a WC-10Co sample polarized in a $\mathrm{NH}_{4} \mathrm{OH}-\left(\mathrm{NH}_{4}\right)_{2} \mathrm{CO}_{3}$ solution: (a) SEM image of the reacted surface, (b-c) magnified views and (d) optical image at 200x magnification. The pitted area is encircled in the optical image.

The lower current density obtained with $\mathrm{WC}-10 \mathrm{Co}$, in the presence of $\mathrm{CO}_{3}{ }^{2-}$ ions, may be attributed to the formation of sparingly soluble cobalt carbonate. The 
magnification of the lighter portions of Fig. 9(a) (see Fig. 9c) further reveals the course of WC-10Co dissolution behavior in the presence of $\mathrm{CO}_{3}{ }^{2-}$ ions.

According to EDX analysis, point 1 in Fig. 9(c) represents the active WC-10Co surface. The lighter portion in point 2 has a high concentration of cobalt, which represents the cavities left out due to the dissolution of $\mathrm{W}$.

Therefore, SEM-EDX analysis indicates that $\mathrm{W}$ dissolved away in the ammonia during anodic polarization and that cobalt remained there as a passive film in the form of carbonate compounds, thus diminishing the anodic current density.

Fig. 10 shows the schematic representation of the WC-Co dissolution mechanisms in the presence of different electrolytes. It clearly indicates that the extent of dissolution is observed to be higher in the case of $\mathrm{Cl}^{-}$ions (Fig 10 (d)), because $\mathrm{Cl}^{-}$ions are highly aggressive and avoid the formation of any passive film on the dissolved surface. However, in the presence of $\mathrm{SO}_{4}{ }^{2-}$ and $\mathrm{CO}_{3}{ }^{2-}$ ions (Fig.10 (b and c)), the dissolution behavior is observed to be similar, except in the extent of the attacks.

On the basis of surface characterization studies, the anodic dissolution tendency of WC-10Co in different $\mathrm{NH}_{4} \mathrm{OH}^{-}$additive electrolyte combinations follows the order $\quad \mathrm{NH}_{4} \mathrm{OH}-\mathrm{NH}_{4} \mathrm{Cl}>\mathrm{NH}_{4} \mathrm{OH}-\left(\mathrm{NH}_{4}\right)_{2} \mathrm{SO}_{4}>\mathrm{NH}_{4} \mathrm{OH}-\left(\mathrm{NH}_{4}\right)_{2} \mathrm{CO}_{3}$. This is analogous to the trend obtained with the anodic current density which is: $\mathrm{NH}_{4} \mathrm{OH}-\mathrm{NH}_{4} \mathrm{Cl}\left(819.1 \mathrm{~mA} / \mathrm{cm}^{2}\right)>\mathrm{NH}_{4} \mathrm{OH}-\left(\mathrm{NH}_{4}\right)_{2} \mathrm{SO}_{4}\left(812.8 \mathrm{~mA} / \mathrm{cm}^{2}\right)>\mathrm{NH}_{4} \mathrm{OH}-$ $\left(\mathrm{NH}_{4}\right)_{2} \mathrm{CO}_{3}\left(761.3 \mathrm{~mA} / \mathrm{cm}^{2}\right)$.

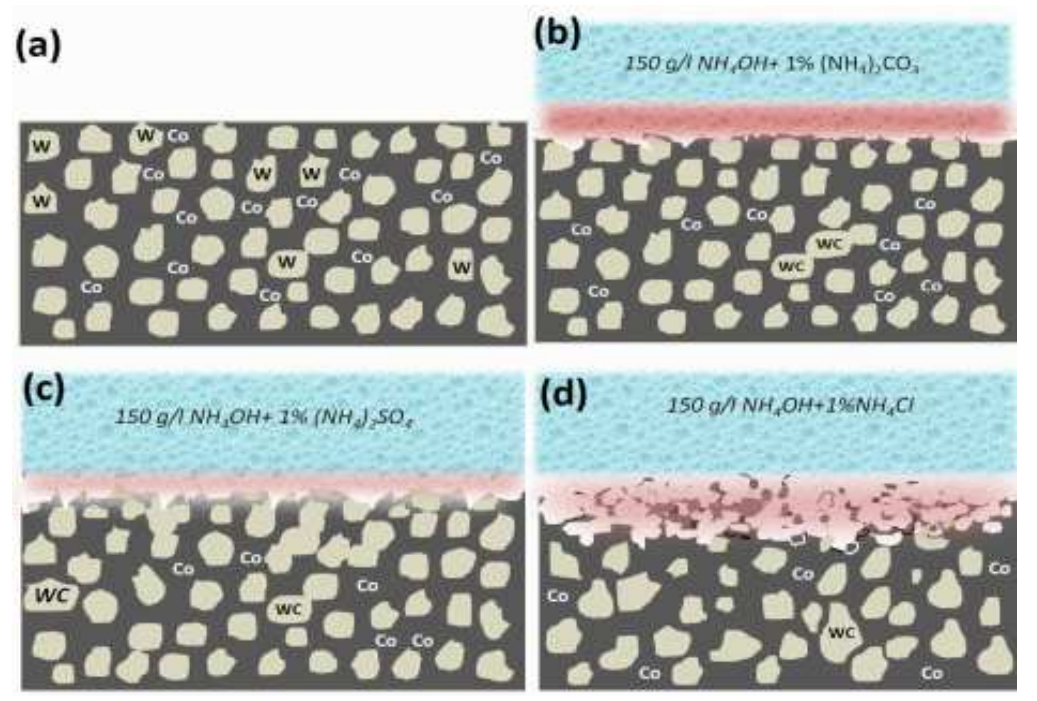

Figure 10. Schematic representation of the WC-Co dissolution mechanisms in the presence of different electrolytes: (a) WC-Co materials, (b) $150 \mathrm{~g} / \mathrm{L} \mathrm{NH} \mathrm{NH}_{4} \mathrm{OH}+1 \%$ $\left(\mathrm{NH}_{4}\right)_{2} \mathrm{CO}_{3}$, (c) $150 \mathrm{~g} / \mathrm{L} \mathrm{NH} 4 \mathrm{OH}+1 \%\left(\mathrm{NH}_{4}\right)_{2} \mathrm{SO}_{4}$ and (d) $150 \mathrm{~g} / \mathrm{L} \mathrm{NH} 4 \mathrm{OH}+1 \% \mathrm{NH}_{4} \mathrm{Cl}$, where the gray field and the embedded particles represent the cobalt matrix and tungsten carbide phases.

Hence, this preliminary study has been intended to find the optimum parameter, selection of suitable electrolytes and additives, as well as the dissolution behavior of WC-Co using the potentiodynamic polarization tests. $\mathrm{W}$ and Co are rare metals, and their extraction implies additional costs. Hence, the development of new electrochemical recycling methods to recycle the WC-Co tool bits scrap 
could be an excellent resource of tungsten and cobalt, which can reduce the cost of these materials. In addition, this process is single step, easy to use and consumes much less energy. Moreover, this study has also been very useful to understand the inherent electrochemical dissolution mechanisms of WC-Co materials, in order to recycle the WC tool bits scrap.

\section{Conclusions}

The electro-dissolution behavior of WC-10Co in an ammoniacal electrolyte with different additives was investigated using potentiodynamic polarization studies. On the basis of factors such as maximum anodic current density and OCP, the dissolution susceptibility was studied. The magnitude of anodic current density in an ammoniacal electrolyte enhanced many folds upon the addition of ammonium salts. The suitability of the additives in an ammoniacal electrolyte for the electrochemical dissolution of WC-10Co followed the order: $\mathrm{NH}_{4} \mathrm{OH}$ $\mathrm{NH}_{4} \mathrm{Cl}>\mathrm{NH}_{4} \mathrm{OH}-\left(\mathrm{NH}_{4}\right)_{2} \mathrm{SO}_{4}>\mathrm{NH}_{4} \mathrm{OH}-\left(\mathrm{NH}_{4}\right)_{2} \mathrm{CO}_{3}$. The optical microscopic and SEM-EDX analysis investigations confirmed the preferential dissolution of tungsten in the ammoniacal electrolyte. Distinct morphological structures composed of cobalt and additive anions were found on the reacted surface of WC-10Co samples. Our studies showed that 5\%(w/v) $\mathrm{NH}_{4} \mathrm{Cl}$ mixed with $150 \mathrm{~g} / \mathrm{L}$ of an ammonia solution is a potential electrolyte for the electrodissolution of tungsten carbide to recover tungsten and cobalt.

\section{Acknowledgments}

The authors are grateful to Dr. R.K. Jana, CSIR-NML for the help in the potentiodynamic experiments. Authors also thank the Director, CSIR-NML, Jamshedpur, for his permission to publish this work.

\section{References}

1. Arsecularatne JA, Zhang LC, Montross C. Inter J Machine Tool Manu. 2006;46:482.

2. Katiyar PK, Singh PK, Singh R, et al. Int J Refract Met Hard Mater. 2016;54:27.

3. Kieffer B, Baroch EF. in Proceedings of a Symposium Sponsored by the TMS-A1ME Refractory Metals Committee and the Physical Chemistry of Extractive Metallurgy Committee at the 110th AIME Annual Meeting. Sohn HY, Carlson ON, Smith JT, Eds., Chicago, IL, 1989. p. 273.

4. Venkateswaran S, Schubert WD, Lux B, et al. Inter J Refract Met Hard Mater. 1996;14:263.

5. Lohse M. US Patent 5993756; 1999.

6. Avery HS. US Patent 2704240; 1995.

7. Martin BE, Titsko JE, Acla HL. US Patent 4255397; 1981.

8. Fruchter M, Moscovici A. US Patent 4629503; 1986.

9. Seegopaul P, Gao L. US Patent 6524366; 2003. 
10. Gurmen S, Friedrich B. World Metall Erzmet. 2004;57:143.

11. Zaichenko VN, Fomayuk SS, Krasnov YS, et al. J Appl Chem. 2010;83:1660.

12. Kuntyi OI, Yavorskyi VT, Iyashkiy VR, et al. Chem Eng Comm. 2012;199:838.

13. Lin JC, Lin JY, Jou SP. Hydrometallurgy. 1996;43:47.

14. Schiesser R. Wertstoff-Recycling wolframha"ltigerSekunda "rrohstoffe. Doctoral thesis. TU-Vienna (in German); 2003.

15. Srinivasan GN, Varadharaja R, Abdulkader JAM. J Appl Electrochem. 1994;24:1191.

16. Devydov AD, Shaldaev VS, Malofeeva AN. J Appl Electrochem. 1997;27:351.

17. Hochstrasser(-Kurz) S, Mueller Y, Latkoczy C, et al. Corros Sci. 2007;49:2002.

18. Vanderpool CD, Kim TK. US Patent 5021133; 1991.

19. Katiyar PK, Randhawa NS, Hait J, et al. Adv Mater Res. 2014;828:11.

20. Hairunnisha S, Sendil GK, Rethinaraj JP, et al. Hydrometallurgy. 2007;85:67.

21. Yang et al., US Patent 0048968; 2011.

22. Malyshev VV, Hab AL. Mater Sci. 2004;40:555-559.

23. Latha TM, Venkatachalam S. Hydrometallurgy. 1989;22:353.

24. Paul RL, TeRiele WAM, Nicol MJ. Int J Miner Proc. 1985;15:41.

25. Vanderpool et al, US Patent 4385972; 1983.

26. Vanderpool et al., US Patent 4283258; 1981.

27. Lin JC, Lin JY, Lee SL. US Patent 541617; 1995.

28. Kobayakawa HY. US Patent 4140597; 1979.

29. Ghandehari MH. J Electrochem Soc. 1980;127:2144.

30. Nutzel. US Patent 4349423; 1982.

31. Vogel AI. A text book of quantitative inorganic analysis. $4^{\text {th }}$ Ed. London: Longmans; 1978.

32. Weidman MC, Esposito DV, Hsu JJ, et al. J Electrochem Soc. 2010;157:179.

33. Rad MH, Ahmadian M, Golozar MA. Inter J Refract Met Hard Mater. 2012;35:62.

34. Kellner FJJ, Hildebrand H, Virtanen S. Inter J Refract Met Hard Mater. 2009;27:806.

35. Human AM, Exner HE. Mater Sci Eng. 1996;209:180.

36. Sutthiruangwong S, Mori G, Kosters R. Inter J Refrac Met Hard Mater. 2005;23:129.

37. Anik M. Corros Sci. 2006;48:4158.

38. Anik M, Osseo-Asare K. J Electrochem Soc. 2006;149:B224.

39. Pednekar SP. Corrosion. 1997;53:814.

40. Jayaraman TR, Venkatean V, Udvpa HVK. Electrochim Acta. 1975;20:209. 